\title{
Kontribusi Kebiasaan Belajar terhadap Motivasi Berprestasi Siswa Serta Implikasinya dalam Pelayanan Bimbingan dan Konseling
}

\author{
Maria Oktasari \\ Universitas Indraprasta PGRI Jakarta. Korespondensi: JI. Nangka No. 58 C (TB. Simatupang), \\ Jakarta Selatan, DKI. Jakarta, Indonesia. E-mail: maria.oktasari@unindra.ac.id.
}

\section{Article Info}

History of Article

Submited November 2019

Accepted November 2019

Published November 2019

\section{Key Word}

Achievement Motivation,

Study Habits,

Guidance and Counseling.

\section{Kata Kunci}

Motivasi Berprestasi,

Kebiasaan Belajar,

Bimbingan dan Konseling.

\begin{abstract}
The purpose of the study was to determine the contribution of learning habits to student achievement motivation. The research method uses quantitative methods. The population of this study includes all students of class $X, X I$ and XII of SMA Master Depok with105 students. The research sample was taken using saturated sampling technique so that the sample was 105 people. Hypothesis testing in research uses simple regression analysis. The results showed that learning habits contribute to student achievement motivation.
\end{abstract}

\begin{abstract}
Abstrak
Tujuan dari penelitian adalah untuk mengetahui kontribusi kebiasaan belajar terhadap motivasi berprestasi siswa. Metode penelitian menggunakan metode kuantitatif. Populasi dalam penelitian ini mencakup seluruh siswa kelas X, XI dan XII SMA Master sebanyak 105 orang siswa. Penarikan sampel penelitian dilakukan dengan menggunakan teknik sampling jenuh sehingga sampel berjumlah 105 orang. Pengujian hipotesis dalam penelitian menggunakan analisis regresi sederhana. Hasil penelitian menunjukkan bahwa kebiasaan belajar berkontribusi terhadap motivasi berprestasi siswa.
\end{abstract}

\section{Citation Info}

Oktasari, M. (2019). Kontribusi kebiasaan belajar terhadap motivasi berprestasi siswa serta implikasinya dalam pelayanan bimbingan dan konseling. Biblio Couns: Jurnal Kajian Konseling dan Pendidikan. 2(3), 117-123. 


\section{PENDAHULUAN}

Sekolah sebagai salah satu lembaga pendidikan formal, mempunyai peranan penting untuk mewujudkan cita-cita siswa serta mengembangkan segala potensi yang dimilikinya. Syamsu dalam Supriatna (2011) menjelaskan siswa merupakan individu yang berada dalam proses berkembang atau menjadi (becoming), yaitu berkembang ke arah kematangan atau kemandirian, sehingga sekolah sebagai lembaga penyelengara pendidikan harus mampu mengembangkan kemampuan yang dimiliki siswa.

Akan tetapi, proses siswa dalam mengembangkan kemampuannya tidak selalu berlangsung secara mulus, atau lepas dari masalah. Dengan kata lain, proses berkembangnya siswa tidak selalu sejalan atau searah dengan potensi, harapan dan nilai-nilai yang dianut. Sehingga dalam belajar siswa harus memiliki beberapa hal, salah satunya adalah motivasi berprestasi.

Motivasi berprestasi merupakan salah satu hal yang harus dimiliki dalam diri siswa. mengapa harus dimiliki oleh siswa? karena, dalam kegiatan belajar di sekolah, motivasi berprestasi terwujud dalam daya penggerak pada siswa untuk mengusahakan kemajuan dalam belajar dan mengejar taraf prestasi maksimal, demi pengayaan diri sendiri dan penghargaan terhadap diri sendiri (Winkel, 2007) . Dengan kata lain, motivasi berprestasi merupakan salah satu faktor penting yang menentukan keberhasilan belajar siswa di sekolah.

Keberhasilan belajar yang dicapai oleh siswa digunakan untuk mengevaluasi kegiatan belajar yang pernah dilakukan. Evaluasi tersebut digunakan untuk melihat apakah yang dilakukannya sesuai dengan kriteria atau standar yang telah ditetapkannya atau belum, karena pada prinsipnya hal tersebut berkaitan dengan dorongan mencapai harapan untuk sukses dan kecenderungan untuk menghindari kegagalan. Hal tersebut dapat diartikan bahwa ketika siswa mempunyai motivasi berprestasi yang tinggi, maka siswa akan beranggapan bahwa prestasi merupakan suatu hal yang harus diraih, diperjuangkan, dan dibanggakan. sebaliknya, bagi siswa yang mempunyai motivasi berprestasi rendah, meningkatkan prestasinya merupakan suatu hal yang sulit untuk diwujudkan (Oktasari, 2017).

Pada kenyataannya hal di atas bertentangan dengan beberapa hasil penelitian, antara lain: Penelitian Adiningtyas (2015) yang menjelaskan bahwa dilihat dari kondisi awal motivasi berprestasi yang dimiliki siswa sebelum diberikan perlakuan, untuk kelompok kontrol dan eksperimen berada dalam kategori rendah. Selanjutnya, hasil penelitian Alit juga menunjukkan motivasi berprestasi siswa berada dalam kategori cukup (Alit, 2003).

Selanjutnya, berdasarkan keterangan dari guru SMA Master Depok, didapatkan informasi bahwa ada beberapa indikasi yang menunjukkan bahwa siswa diduga masih mempunyai motivasi berprestasi rendah, Hal tersebut terlihat dari: (1) beberapa siswa kurang bersemangat mengikuti beberapa pelajaran tertentu, (2) ketika guru menjelaskan materi pelajaran, beberapa siswa kurang memperhatikan gurunya, (3) dalam belajar, beberapa siswa tidak memiliki target nilai yang akan dicapai, (4) Jika mendapatkan tugas yang sulit, beberapa siswa hanya mengerjakan 
tugas yang mudah saja, (5) Jika mendapatkan pekerjaan rumah, beberapa siswa mengerjakannya di sekolah. Penjelasan tersebut mengindikasikan bahwa motivasi berprestasi siswa masih rendah dan perlu ditindaklanjuti.

Motivasi berprestasi dipengaruhi oleh beberapa faktor, yaitu: faktor dari dalam diri dan faktor dari luar diri siswa. Martianah (1984) menjelaskan beberapa faktor yang mempengaruhi motivasi berprestasi, yaitu: (1) kemampuan: dorongan penggerak untuk mencapai keberhasilan belajar melalui latihan belajar, (2) kebutuhan: menjadikan kebutuhan sebagai kekurangan sehingga menimbulkan kehendak untuk memenuhi atau mencukupinya seperti halnya kebiasaan belajar, (3) minat: kecenderungan yang menetap dalam diri individu, dan (4) harapan/keyakinan: kemungkinan untuk memenuhi suatu kebutuhan dari individu.

Berdasarkan penjelasan di atas, maka salah satu faktor yang mempengaruhi motivasi berprestasi adalah kebiasaan belajar. Kebiasaan belajar merupakan perilaku belajar seorang individu yang tertanam dalam waktu yang relatif lama sehingga memberikan ciri dalam aktivitas belajar yang dilakukannya (Aunurrahman, 2009). Artinya kebiasaan belajar yang baik dapat dilakukan secara berulang oleh siswa dengan cara latihan sehingga menjadi kebiasaan yang melekat pada diri siswa.

Namun, berdasarkan keterangan dari guru SMA Master Depok, kebiasaan belajar siswa masih kurang baik, hal tersebut terlihat dari :1) masih ada beberapa siswa masih datang terlambat, 2) masih adda beberapa siswa yang mengerjakan tugas di sekolah, 3) siswa terlambat dalam mengumpulkan tugas, 4) masih ada beberapa siswa yang duduk-duduk di kantin ketika jam pelajaran sudah dimulai, 5) masih ada beberapa siswa yang sering minta izin ke luar kelas. Hal tersebut mengindikasikan bahwa kebiasaan belajar siswa di sekolah masih kurang baik.

Permasalahan diatas menunjukkan bahwa siswa yang memiliki kebiasaan belajar yang kurang baik diduga disebabkan karena siswa memiliki motivasi berprestasi yang rendah sehingga siswa tidak mencapai keberhasilan belajar yang maksimal. untuk membuktikan hal terebut maka penulis telah melakukan penelitian tentang kontribusi kebiasaan belajar terhadap motivasi berprestasi siswa di SMA Master Depok.

\section{METODE}

Metode yang digunakan dalam penelitian ini adalah metode kuantitatif yang bertujuan untuk mendeskripsikan dan menguji kontribusi kebiasaan belajar terhadap motivasi berprestasi siswa. Populasi dalam penelitian ini adalah mencakup seluruh siswa kelas X, XI dan XII SMA Master Depok sebanyak 105 orang siswa. Penarikan sampel dalam penelitian ini menggunakan teknik sampling jenuh sehingga sampel penelitian berjumlah 105 orang siswa. Instrumen penelitian yang digunakan adalah skala motivasi berprestasi yang dikembangkan Maria Oktasari dan skala kebiasaan belajar yang dikembangkan Riska Andriani. Adapun pengujian hipotesis dalam penelitian ini menggunakan analisis regresi sederhana. 
HASIL

Untuk mengetahui ada tidaknya hubungan antara kebiasaan belajar terhadap motivasi berprestasi maka dilakukan uji hipotesis. Adapun hasil uji hipotesis yang dilakukan sebagai berikut:

\section{Hubungan kebiasaan belajar terhadap motivasi berprestasi}

Untuk menguji hipotesis ada tidaknya pengaruh kebiasaan belajar terhadap motivasi berprestasi digunakan uji regresi sederhana, adapun hasil pengujiannya disajikan dalam tabel 1 berikut:

Tabel 1 Hasil Perhitungan Pengujian Koefisien Korelasi Varibel $\mathbf{X}$ terhadap $\mathbf{Y}$ Model Summary

\begin{tabular}{ccc} 
Model & $\mathrm{R}$ & $\mathrm{R}$ Square \\
\hline $\mathbf{1}$ & .624 &, 390 \\
\hline
\end{tabular}

Tabel di atas menjelaskan bahwa hasil yang diperoleh dalam penelitian ini, nilai $R$ sebesar 0.624 dan nilai $R$ Square (R2) sebesar 0.390. Hal tersebut bermakna bahwa terdapat hubungan antara $\mathrm{X}$ dengan $\mathrm{Y}$, dan kontribusi $\mathrm{X}$ terhadap $\mathrm{Y}$ adalah sebesar $39,0 \%$.

Tabel 2 Hasil Pengujian Signifikansi Koefisien Regresi Variabel $X$ terhadap $Y$

\begin{tabular}{llccc}
\hline \multicolumn{5}{c}{ ANOVA $^{\mathbf{b}}$} \\
\hline Model & Variabel & $\mathrm{F}_{\text {tabel }}$ & $F_{\text {hitung }}$ & Sig. \\
\hline $\mathbf{1}$ & $\mathrm{X}-\mathrm{Y}$ & 65.752 & 3.94 & 0.000 \\
\hline
\end{tabular}

Tabel di atas menunjukkan nilai $F_{\text {hitung }}$ adalah 65.752 , sedangkan nilai $F_{\text {tabel }}$ adalah 3.94, berarti $F_{\text {hitung }}>F_{\text {tabel }}$ dengan taraf signifikansi 0.000 yang lebih kecil dari 0.05. Hal ini berarti bahwa kebiasaan belajar dapat digunakan untuk memprediksi besarnya angka-angka variabel motivasi berprestasi. Dengan demikian, dapat dinyatakan bahwa kebiasaan belajar berkontribusi secara signifikan terhadap motivasi berprestasi siswa.

Tabel 3 Hasil Perhitungan Persamaan Regresi Variabel X terhadap Y

\begin{tabular}{cccc}
\hline Model & \multicolumn{2}{c}{ Coefficients $^{\mathbf{a}}$} & \\
\hline & $\begin{array}{c}\text { Unstandardized } \\
\text { Coefficients }\end{array}$ & $\mathbf{T}$ & sig. \\
\cline { 2 - 3 } (Constant) & B & \\
\hline Kebiasaan Belajar & 44.574 & 5.630 &, 000 \\
\hline \hline
\end{tabular}

a. Dependent Variable: Motivasi Berprestasi

Tabel 3 di atas, menunjukkan bahwa thitung sebesar 8.109 dengan nilai signifikansi sebesar 0.000, jika dibandingkan dengan Sig.Alpha, maka nilai 
signifikansi lebih kecil dari Sig.Alpha $(0.000<0.05)$ dan nilai thitung bernilai negatif (8.109). Hal ini berarti kebiasaan belajar berkontribusi positif yang signifikan terhadap motivasi berprestasi siswa sebesar $44.5 \%$. Artinya, semakin baik kebiasaan belajar maka semakin tinggi motivasi berprestasi siswa. Berdasarkan Tabel 3 tersebut dapat digambarkan persamaan regresinya sebagai berikut: $\tilde{Y}=44.574+(0.568 \mathrm{X})$.

\section{PEMBAHASAN}

Hasil penelitian menjelaskan bahwa kebiasaan belajar berkontribusi secara signifikan terhadap motivasi berprestasi. Hal tersebut dapat dilihat dari rangkaian analisis data yang menunjukkan bahwa kontribusi kebiasaan belajar terhadap motivasi berprestasi sebesar 39.0\% sisanya dipengaruhi oleh variabel lain. Maknanya bahwa kebiasaan belajar merupakan salah satu faktor yang berkontribusi terhadap motivasi berprestasi siswa.

Hal ini sejalan dengan pendapat Martianah (1984) yang menjelaskan bahwa salah satu faktor yang mempengaruhi motivasi belajar adalah kebiasaan belajar. Artinya siswa yang memiliki kebiasan belajar yang baik, maka siswa tersebut memiliki motivasi berprestasi yang tinggi. Sebaliknya, jika siswa memiliki kebiasaan belajar yang tidak baik, maka siswa memiliki motivasi berprestasi yang rendah.

Selanjutnya, Covey (2010) menjelaskan kebiasaan merupakan faktor yang kuat dalam diri karena konsisten dan sering merupakan pola yang tidak disadari, maka kebiasaan secara terus menerus, setiap hari, mengekspresikan karakter, dan menghasilkan efektivitas atau ketidakefektifan. Kemudian kebiasaan sebagai titik pertemuan dari pengetahuan, keterampilan, dan keinginan. Jika dikaitkan dengan kebiasaan belajar, maka kebiasaan belajar merupakan dorongan penggerak untuk melakukan kegiatan belajar secara terus menerus tanpa adanya rasa terpaksa.

Lebih lanjut, Bandura (Santrock, 2009) menjelaskan bahwa Iklim dan prestasi dari seluruh sekolah mempengaruhi motivasi siswa. Selanjutnya, menurut Osa-Edon \& Alutu (dalam Mendezabal, 2013) bahwa terdapat korelasi antara kebiasaan belajar siswa dengan prestasi akademik. Kemudian, hasil penelitian Lidgren (dalam Gie, 1995) menunjukkan bahwa kebiasaan belajar berperan penting dalam kesuksesan akademik, sehingga perlu dicarikan solusi untuk meningkatkan kebiasaan belajar siswa agar prestasi akademik siswa dapat meningkat. Berdasarkan penjelasan tersebut, bahwa kebiasaan belajar yang baik dimulai dari diri sendiri dengan membiasakan dan mendisiplinkan diri dalam belajar kemudian memiliki motivasi berprestasi sehingga selanjutnya siswa tersebut memiliki prestasi dalam akademik.

Berdasarkan penjelasan tersebut, dapat dipahami bahwa begitu pentingnya motivasi berprestasi untuk mencipatkan kebiasaan belajar yang baik pada siswa. Oleh sebab itu, guru BK atau Konselor dan guru mata pelajaran bertanggungjawab untuk meningkatkan motivasi berprestasi siswa. Guru BK/Konselor dapat menjadikan hasil penelitian sebagai pedoman untuk membuat program layanan bimbingan dan konseling. Pemberian layanan bimbingan kelompok dan layanan penguasaan konten merupakan contoh alternatif layanan yang dapat diberikan untuk meningkatkan kebiasaan belajar siswa. Sesuai dengan manfaat dari layanan bimbingan kelompok 
yaitu membantu siswa untuk dapat mencapai perkembangan secara optimal sesuai dengan kemampuan, bakat, minat serta nilai-nilai yang dianutnya. Hal tersebut juga bertujuan untuk mencegah munculnya masalah pada siswa dalam mengembangkan potensinya.

\section{SIMPULAN}

Temuan Peneltitian menunjukkan bahwa kebiasaan belajar berkontribusi terhadap motivasi berprestasi. Artinya motivasi berprestasi dipengaruhi oleh kebiasaan belajar. Selanjutnya, penelitian ini memiliki keterbatasan yaitu: dilaksanakan dengan populasi siswa SMA Master Depok diduga memiliki karekteristik tertentu, yang mungkin berbeda dengan karakteristik siswa SMA lainnya. Oleh karena itu, peneliti selanjutnya diharapkan dapat menindaklanjuti penelitian ini dengan jumlah sampel yang lebih besar dan jangka waktu yang relatif lebih lama, pada beberapa sekolah yang memiliki kemungkinan mengalami masalah-masalah yang sama dengan penelitian ini.

Pengumpulan data kuantitatif dalam penelitian ini hanya menggunakan skala motivasi berprestasi dan kebiasaan belajar yang ditujukan kepada siswa. Oleh karena itu, bagi peneliti selanjutnya perlu dilakukan pendalaman data dengan menggunakan berbagai metode pengumpulan data lainnya, maupun jenis dan tingkatan penelitian yang berbeda.

\section{DAFTAR RUJUKAN}

Adiningtiyas, S. W. 2015. "Efektivitas Layanan Informasi dengan Media untuk Meningkatkan Motivasi Berprestasi Siswa”. Tesis tidak diterbitkan. Padang: Prodi S2 BK FIP UNP.

Alit, D. M. (2003). Kontribusi Faktor Lingkungan Sekolah, Lingkungan Keluarga, dan Motivasi Berprestasi terhadap Nilai Modern Siswa Sekolah Lanjutan Tingkat Pertama (SLTP) di Kabupaten Gianyar, Bali. Jurnal Penelitian Dan Evaluasi Pendidikan, 5(6).

Aunurrahman. (2009). Belajar dan Pembelajaran. Bandung: Alfabeta.

Covey, S. R. 2010. The 7 Habits of Highly Effective People. Terjemahan oleh Budijanto. Jakarta: Bina Aksara.

Gie, T. L. 1995. Cara Belajar yang Efisien. Yogyakarta: Liberty.

Mendezabal, M. J. N. 2013. "Study Habits and Attitudes: The road to academic success". Open Science Repository Education, (Online). (http://www.openscience-repository.com/study-habits-and-attitudes-the-road-to-academicsuccess.html, diakses Maret 2016).

Oktasari, M. (2017). Perceptions around teacher â€TM $\mathrm{S}$ social support with student achievement motivation, 1(2), 145-150. 
Biblio Couns : Jurnal Kajian Konseling dan Pendidikan | Vol. 2 No. 3 November 2019

Santrock, J. W. (2009). Adolescence (Perkembangan Remaja), Alih Bahasa Shinto B. Adelar Dan Sherly Saragih, Jakarta: Erlangga.

Winkel, W. S. (2007). Psikologi pendidikan dan evaluasi belajar. Gramedia. 